\title{
XI. Description and use of the dynanometer, or instrument for ascertaining the relative strength of men and animals
}

\section{Cit. Regnier}

To cite this article: Cit. Regnier (1798) XI. Description and use of the dynanometer, or instrument for ascertaining the relative strength of men and animals, Philosophical Magazine Series 1, 1:4, 399-404, DOI: $10.1080 / 14786447808676858$

To link to this article: http://dx.doi.org/10.1080/14786447808676858

曲 Published online: 25 Jan 2010.

Submit your article to this journal $\pi$

Џll Article views: 3

Q View related articles $\sqsubset$ 
When the mixture has boiled half an hour, pour it into a flat veffel, in order that the charcoal my fubfide to the bottum; then pour off the liquid, and place it over the fire once more, that the fuperfluous water may evaporate, and to give to the molaffes their former confiftence. Twentyfour pounds of molaffes will produce twenty-four pounds of fyrup.

This method has been employed on a large fcale with the happieft effects; the molaffes become fenfibly milder, and can be employed in many articles of food; though in dithes where milk is ufed, or for cordials mixed with fpices, fugar is to be preferred.

XI. Defcription and Ufe of the Dynanometer, or Inftrument for afcertaining the relative Strengtb of Men and Animals. Invented by Cit. Regnier. From Journal de l'Ecole Polytechnique, Vol. II. 6 th Year.

W

HEN Sanctorius invented his balance, he taught us what we lofe by infenfible perfiration; and no one, without this difcovery, would perhaps ever have imagined that the matter thrown out from the body is more than half what we receive as nourifiment. Knowledge no lefs important might be acquired, had we the eafy means of afcertaining, in a comparative manner, our relative ftrengths at the different periods of life, and in difierent ftates of health. Buffon and Gueneau, who had fome excellent ideas on this fubject, requefted me to endeavour to invent a portable machine, which, by an eafy and fimple mechanifm, might conduct to a folution of this queftion, on which they were then engaged. Thefe philofophers were acquainted with that invented by Graham, and improved by Dr. Defaguliers, at London; but this machine, conftructed of wooden-work, was too bulkly and heavy to be portable; and, befides, to make experiments on the different parts of the body, feveral 
machines were neceffary, each fuited to the part required to be tried. They were acquainted alfo with the dynanometer of Cit. Leroy of the Academy of Sciences at Paris. It confifted of a metal tube ten or twelve inches in length, placed vertically on a foot like that of a candleftick, and containing in the infide a fpiral fpring, having above it a graduated thank terminating in a globe. This thank, together with the fpring, funk into the tube in proportion to the weight acting upon it, and thus pointed out, in degrees, the frength of the perfon who preffed on the ball with his hand.

This inftrument, though ingenious, did not appear fufficient, however, to Buffon and Gueneau; for they wifhed not merely to afcerfain the mufeutar force of a finger or hand, but to eftimate that of each limb feparately, and of all the parts of the body. I fhall not here give an account of the attempts I made to fulfil the withes of thefe two phitofophers; but only obferve, that in the courfe of my experiments I had reafon to be convinced that the conftruction of the inftrument was not fo eafy as might have been expected. Befides the ule which an enlightened naturalift may make of this machine, it may be poffible to apply it to many other important purpofes. For example, it may be employed with advantage to determine the ftrength of draught cattle; and, above all, to try that of horfes, and compare it with the ftrength of other animals. It may ferve to make known how far the affifance of well-conftructed wheels may favour the movement of a cartiage, and what is its vis inertice in proportion to the load. We might appreciate by it, alfo, what refiftance the nope of a mountain oppoles to a carriage, and be able to judge whether a carriage is fufficiently loaded in proportion to the number of horfes that are to be yoked to it. In the arts, it may be applied to machines of which we with to afcertain the refiftance, and when we are defirous to calculate the moving force that ought to be adapted to them. It may ferve, alfo 
as a Roman balance to weigh burdens. In fhort, nothing would be more eafy than to convert it into an anemometer, to difcover the abfolute force of the wind, by fitting to it a frame of a determined fize filled up with wax-cloth; and it would not be impoffible to afcertain by this machine the recoil of fire-arms, and confequently the ftrength of gunpowder.

This dynanometer, in its form and fize, has a near refemblance to a common graphometer. It confifts of a fpring twelve inches in length, bent into the form of an elliplis; from the middle of which arifes a femicircular piece of brafs, having engraved upon it the different degrees that exprefs the force of the power acting on the lpring. The whole of this machine, which weighs only two pounds and a half, oppafes, however, more refiftance than may be neceffary to determine the action of the ftrongeft and mont robuft horfe. The frmplicity of its mechanifm will be better illuftrated by the following defcription :

A, an elliptical fpring, feen in perfpective, covered with leather, that it may not hurt the fingers when ftrongly preffed on with the hands, (Jee Plate XIII.) This fpring is compofed of the beft tteel well welded and tempered, and afterwards fubjected to a ftronger proof than is indicated by its graduation, in order that it may not lofe any of its elafticity by ule.

$\mathrm{B}, \mathrm{a}$ piece of Ateel Atrongly faftened to the fpring. by means of a claw and fcrews, in order to fupport a femicircular plate of brafs $\mathrm{C}$, mounted on the fpring, feen geometrically. On this plate are engraved two arcs, one divided into myriagrammes, and the other into kylogrammes. Each of thefe arcs is ftill further divided by points, which exprefs the weight in pounds de marc; and all thefe degrees having been exactly valued by accurate weights, it thence refults that all dynanometers of this kind may be compared with each other.
Vol. I.
D d
D, a 


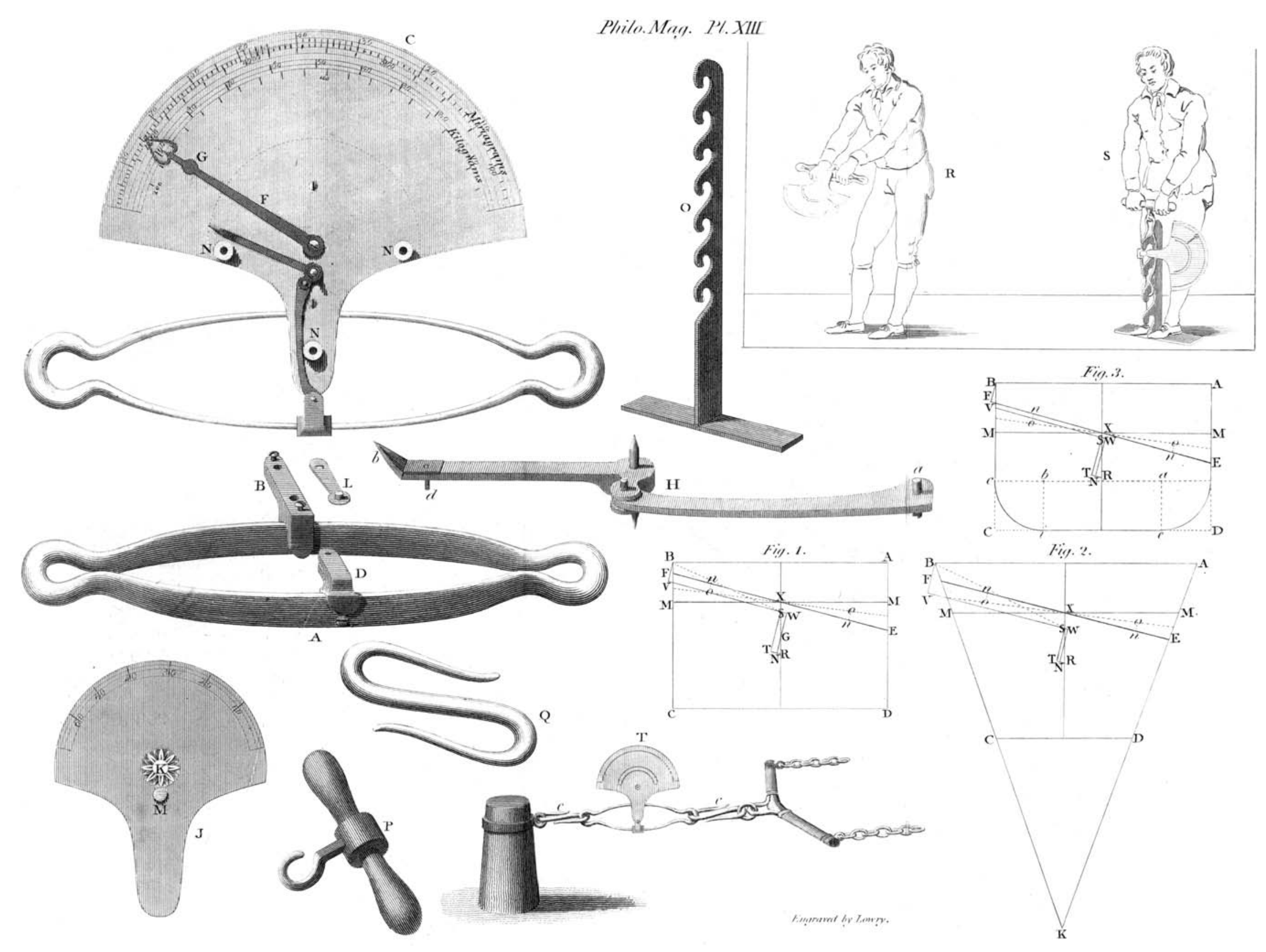


D, a fmall fteel fupport, adjufted like the former to the other branch of the fpring, and having a cleft towards its upper extremity to receive freely a fmall copper lever $E$, which is kept in its place by a fmall fteel pin $a$. The whole of this mechanifm is feen of its full fize at $H$.

F, a fteel index, very light and elaftic, fixed upon its axis by a fcrew in the centre of the brafs femicircle. This index has a fmall bit of leather or cloth glued upon the fmall circular part $G$, in order to render the friction on the plate eafy, uniform, and almolt infenfible. It is to be obferved, that this index is terminated by a double point, adapted to the divifions on both the femicircular arcs. The firt, divided into myriagrammes and points, expreffing ten pounds de marc, ferves for all experiments which oblige the fpring to be elongated in the direction of its greater axis, as is the cale in trying the ftrength of the reins; in a word, for all trials where it is neceffary to draw the fpring by the two ends. The fecond, divided into kylogrammes and points, expreffing pounds de marc, is deftined for experiments which comprefs the two fides of the fpring, as in trying the force of the hands.

J, a fmall plate of brafs which covers the mechanifm, to prevent it from being injured. This fmall plate has on it alfo a divided arc, the degrees of which correfpond with thofe of the firft arc of the machine; and by the play of a fmall index $b$, which is under the plate, the movements of the fpring may be afcertained.

$\mathrm{K}$, an aperture in the covering plate, through which may be introduced a fmall turnfcrew, for the purpofe of tightening ar eafing the index as may be neceffary.

$L$, a pallet of brafs, with a fcrew, having a cap like that on the needle of the mariner's compafs, in which the lower pivot of the lever, that puthes round the index or handle, is made to play. This pallet, acting as a fpring, yields to any fudden fhock, and prevents the derangement of the mechanifm. 
$M$, a focket riveted on the plate $J$, in which the upper pivot of the lever turns.

$\mathrm{N}, \mathrm{N}, \mathrm{N}$, fmall cylindric pillars that fupport the covering plate, which is fixed to them by three fcrews.

$\mathbf{O}$, an iron rack, on the lower part of which the feet mult be placed when it is intended to try the frength of a perfon's body.

$P$, a double handle of wood, with an iron hook, to be held at the fame time in the two hands.

$\mathbf{Q}$, a double hook made of iron, one end of which is to be hooked to the end of the fpring, and the other to a rope faftened to a ftake, as at $c$, when experiments are to be made on the ftrength of horfes, or others, that require the dynanometer to be fupported by hooks.

$R$, the manner of holding the dynanometer to afcertain the ftrength of the hands.

$S$, pofition of a man when trying the ftrength of his reins.

$T$, difpofition of the dywanometer to try the frength of a horfe or any other draught animal.

The effects of this machine may be thus explained: If a perfon preffes on the fring with the hands, or draws it out lengthwife, by pulling the two extremities in a contrary direction, the two fides of the fpring approach each other; and in proportion as they are brought nearer, the fmall lever of the mechanifm puthes bcfore it the index, which, by the tightnefs with which it is fcrewed in its place, will remain at the point to which it has been brought by the pin $d$, in confequence of the force acting on the fpring.

The mufcular force of the arms, or rather the ftrength of the hands, may be tried by laying hold of the two fides of the fpring neareft to the centre, as may be feen figure $R$; fo that the arms may be a little Aretched, and inclined downwards, almoft at an angle of 45 degrees. This pofition, which appears the moft natural, is alfo the moft convenient for a man to aet with his full force. It is to be

$\mathrm{Dd} 2$ recollected, 
recollected, that the lower arc of divifion, divided into kylogrammes, is that which ferves to exprefs the force of the hands, and of all the actions which prefs the two fides of the fpring. The ftrength of the hands may alfo be tried one after the other; and if an account be kept of the degree of preffure of the right hand, and then of the left, and thefe two fums be added together, it will be found that the fum-total is, in general, equal to the ftrength of both the hands when acting together.

To try the ftrength of the body, or rather the reins, the perfon muft place his feet on the bottom part of the rack $\mathbf{O}$; one of the ends of the fpring is then to be placed in one of the hooks of the rack; and the hook $P$ is to be put into the other end. In this pofition the body is perpendicular; the fhoulders only being inclined a little forwards, to be able, in throwing back the body, to pull the fpring with all the force which a perfon is capable of exerting. In this fituation, reprefented by $S$, a man may raife a great weight without being expofed to thofe accidents which might be occafioned by an effort made in a more conftrained pofition.

Notbing can be more convenient than this dynanometer to afcertain and compare the frength of horfes and that of all draught animals. Figure $\mathrm{T}$ hows, in a fufficient manner, the difpofitions neceffary for experiments of that kind. The trials I made on this fubject are not extenfive; but as they were conducted with care, they may ferve to give a very juft idea of the abfolute force of horfes of middling ftrength. For this purpofe I employed four horfes of middle fize, in good health and well-conditioned, which were fubjected feparately and in fucceffion to the fame trial. The firft drew equivalent to $3^{6}$ myriagrammes; the fecond $3^{8 \frac{1}{2}}$; the third $26 \cdot \frac{\mathrm{I}}{2}$; and the fourth 43 . The fum of all thefe is $144 \mathrm{my}-$ riagrammes; and if we take the mean of this fum, we fhall have, for the ftrength of ordinary horfes, $3^{6}$ myriagrammes, or $73^{6}$ pounds de marc. 